of view of the complete colour sense of man. The guinea pig probably comes very near the totally colour-blind, the cat near the deuteranope. The cat has the typical dominator but no definite 'red' modulator. The guinea pig, however, has a number of different modulators in the short wave-lengths and hence may be able to discriminate colours in this region. But it lacks dominator and Purkinje shift. The totally colour-blind human has a photopic luminosity curve practically identical with the luminosity distribution of the normal dark-adapted eye dominated by visual purple. The guinea pig has the same scotopic and photopic sensitivity curve, slightly distorted by a hump in the blue in the photopic state.

With the three preferential regions for the modulators, it is clear that this theory can do what the trichromatic theory does and also that it demon. strates the essential correctness of Thomas Young's great generalization, although it is necessary to assume a greater or lesser number of somewhat different modulators within these regions. The main crux of the trichromatic theory and, indeed, of any classical theory, is the lack of precision in the concepts accounting for the perception of white as a separate entity which, nevertheless, somehow is intimately connected with the perception of colour. The trichromatic theory regards white as due to the summed effects of, chiefly, the 'red' and the 'green' sensitivity curves. This forces the theory to accept the consequence that removal of 'red' and/or 'green' should cause removal of the perception of luminosity in the same region of the spectrum. Hence there can be no colour-blindness without profound changes in the form and locus of the luminosity curve. It is an admission of failure to have to explain so important a phenomenon as deuteranopia by pushing it aside to be taken care of by the 'higher centres'.

Many of the phenomena to which the trichromatic theory has directed attention need not be discussed for the reason that my theory does not necessarily exclude the explanations already available. Thus, for example, the fineness of colour discrimination in different regions of the spectrum may be explained in the classical way, or else by the assumption that the number of slightly different modulators is particularly great in the regions where the maxima of colour discrimination are placed.

In its present form the theory gives no explanation of contrast colour, though certain alternatives seem reasonable in view of the fact that different elements are so often coupled together and that the retina contains a large number of coupling synapses. If a certain percentage of the 'red' and 'green' modulators are coupled together in such a manner that both are forced to discharge when either is stimulated, the natural result to expect from the asymmetry caused by fatiguing either of them is that the other one should predominate in the neighbouring region as well as in the off-effect. The experiments themselves have not yet dealt with situations calculated to bring forth contrast phenomena.

It is impossible in this brief review to deal with the available evidence concerning the nature of the colour-sensitive substances. The hypothesis I prefer is that visual purple-which may be called the dominator of the scotopic eye-is the mother sub. stance for the photopic dominator and the modulators. Its molecule consists of a protein nucleus serving as carrier for about ten chromophoric groups (see. Broda, Goodeve and Lythgoe ${ }^{7}$ ). The different colour sensitive substances may be due to changes in the linkage between carrier and chromophores.

1 Hartline, Amer. J. Physiol., 121, 400 (1938).

'Granit and Svaetichin, Upsala Läkaref. Förh. N.F., 45, 161 (1939)

${ }^{3}$ Lythgoe, J. Physiol., 89, 331 (1937).

- Dartnell and Goodeve, NATURE, 139, 409 (1937).

${ }^{5}$ Polyak, Arch. Ophthalm., 15, 477 (1936).

- Wright, Proc. Roy. Soc., B, 115, 49 (1934).

? Broda, Goodeve and Lythgoe, J. Physiol., 98, 397 (1940).

\section{DARWIN'S HEALTH}

\section{BY SIR BUCKSTON BROWNE, F.R.C.S.}

DERSONAL experiences of great men are always interesting, and often instructive. There has lately come to light a diary of his health by the immortal Charles Robert Darwin, from 1849 until 1854. It is now in the possession of the British Association for the Advancement of Science ${ }^{1}$, and the Association's Secretary, Dr. O. J. R. Howarth, has permitted me to read it. It consists of thirtyfour pages of unruled foolscap.

There is no doubt that the hardships of his five years voyage on board H.M.S. Beagle seriously affected Darwin's health. At first he tried to live in London, but found it impossible, and he sought a home in the country. He found it at Down House, Downe, Kent, sixteen miles from London, well away from any great road, quiet and secluded. He lived there for the rest of his life, forty years, dying in 1882, aged seventy. three. Down House is roomy, there are a large vegetable and fruit garden and considerable meadow land. It had no water or gas supply, and no bathroom. There was a cesspool-and a well. Cows and pigs were kept, the stables were large, and the dairy and coachman's house were separate buildings. There was a long path, called the "Sand-walk", along the northern side of the meadow land.

When Darwin began this daily account of his health, he had been married for ten years; he had a devoted wife, and a comfortable home, but the diary is a record of continual misery and suffering, although often the days are marked "good", and the good is sometimes underlined or even doubly underlined. His nights are disturbed by severe attacks of flatulence. In the daytime he suffers from attacks of sickness and vomiting. He has headaches and dizziness. He mentions lumbago and arthritis, and most painful of all, a succession of attacks of boils. They are allowed to burst of themselves and no antiseptics are used. One boil is described as "very large". $\mathrm{He}$ has pyorrhoe and sore gums and a tooth has to be extracted under chloroform. He complains that his writing has become very bad.

While the diary was kept, Darwin visited London, Eastbourne, and Great Malvern, where he tried the water-cure, and in a curtained corner of his study at Down House he kept a large shallow tin bath, and in the diary "douches" and "double douches" are mentioned. At the time a so-called electric belt was much advertised; it was tried and abandoned.

Darwin daily walked in his garden and up and down the "Sand-walk", and rode about the neighbourhood on a stout cob. After early manhood he smoked only occasionally. He became a regular snuff taker, but in order to keep the habit in abeyance kept his snuff jars in the hall, so that when desiring a pinch he had to rise and leave the room. 
Darwin's last remaining son, Major Leonard Darwin, R.E., born in 1850, has given me the following particulars of his father's daily meals. He generally breakfasted alone; tea, with sugar, milk or cream, toast and a little bacon. He lunched with his family -joint, vegetables, and a simple sweet pudding. $\mathrm{H}_{\Theta}$ drank a glass of sherry. He had afternoon tea with Mrs. Darwin. Dinner was a repetition of luncheon, and sherry was again taken. He never took ales or spirits, but often drank tea with his dinner.

Many have found the accounts of Darwin's continued ill-health somewhat mysterious. There cannot have been any organic disease, for he lived to be seventy-three, and all seems clear now-he was the victim of chronic indigestion, induced by five years of hardship at sea, with scant accommodation on a mall ship and with roughly prepared food. All this would permanently upset the digestive organs of a highly sensitive man.

Indigestion results from : (1) imperfect mastication; (2) too much food; (3) improper foods. I think the cold baths must have done harm, and it is evident a good dentist should have been consulted, periodically. The stomach should have been called. into action three, and not four, times daily. For many, afternoon tea is an insult to their luncheon and a menace to their dinner. I think his dietary was all wrong, but this is a professional matter not to be discussed in these pages. The sad thing is that there was so much suffering while "Malignant Fate at by and smiled".

NATURA, 150, 535 (1942).

\section{SCIENTIFIC CENTENARIES IN 1943}

\section{By ENG.-CAPt. EDGAR C. SMITH, O.B.E., R.N.}

FoUR hundred years ago, on May 24, 1543, the 1 famous astronomer Nicolaus Copernicus died in the city of Frauenberg, situated on the Fritsches Hof, about midway between Dantzig and Königsberg. He was buried in the cathedral, the centre of the diocese which he had served faithfully through his knowledge of canon law. As he lay on his bed stricken with paralygis, the first copy of his book "De Revolutionibus orbium coelestrum, Libri VI" was placed in his hands, but it was too late; his memory had gone, his faculties were obscured. The book had lain completed for thirteen years, and it was only through the enthusiasm of the young German mathematician, Joachim Rheticus-whose attitude towards Coper. nious was like that of Halley to Newton-that it was at last published. The expense of publishing was bome by Cardinal Schonberg, and to-day the first edition is expeedingly rare. A second edition appeared in i566, and a third and last in 1617. Copernicus was just over seventy years of age, having been born at Thom on January 19, 1473. Through his bishopuncle he was able to study at Cracow, Bologna, Rome, Padua and Ferrara, at the last of which he took his dootor's degree in canon law. He returned north from Italy in 1505, lived at Heilsburg from 1507 until 1512, and from thence onward Frauenberg was his home. There is a statue of him at Thorn and another stands in the interior eourt of the library of the Jagellonian University, Craoow. A photograph of this was published in NATURE of March 2, 1922, to illustrate an artiole on "Science in Poland", and the question as to whether Copernicus was a Pole or a
German was the subject of remarks in these columns so long ago as December 21, 1871 (p. 151).

A century after Copernicus died, John Bainbridge, the first Savilian professor of astronomy at Oxford, passed away "at his house opposite Merton College in this his $62 \mathrm{~d}$ year, and his body was conveyed to the public school, where an oration having been pronounced in honour of him by Mr. William Strode, the University Orator, it was carried to Merton College Church and deposited on the left side of Mr. Henry Brigg's grave and an epitaph was inscribed upon his monument in Latin". Before his appointment to the Savilian chair, Bainbridge had taken degrees at Cambridge, kept a school, practised medicine and written on a comet. To what extent he had been influenced by the views of Copernicus we are not told, but his main interest was in Greek and Arabic scientific writings. A foreign mathematical contemporary of his was Habakkuk Guldinus (1577-1643), a Swiss Protestant who became a Jesuit and taught mathematics with success in the Jesuit colleges at Rome and Gratz.

Passing to the year 1743, we are faced with a long list of men of science, of greater or lesser fame, but all of interest. Of these the outstanding figure is Lavoisier, who was born in Paris on August 16, 1743, and fell beneath the guillotine on May 8, 1794. "The spring sends its green leaves and bright weather, bright May, brighter than ever: Death pauses not. Lavoisier, famed chemist shall die and not live: chemist Lavoisier was Farmer-General Lavoisier too, and all the Farmers-General are arrested; all, and shall give an account of their moneys and incomings, and die for 'putting water in the tobacco' they sold." So wrote Carlyle. Twenty-eight Farmers-General and their three assistants were sentenced at one sitting of the Tribunal of the Terror; and it was then that the terrible Coffinhal immortalized himself by replying to Lavoisier: "The Republic requires neither savants nor chemists; the course of justice cannot be suspended". Condorcet (1743-94), author of works on the calculus, and of "The Progress of the Human Mind", perpetual secretary to the Royal Academy of Sciences, only escaped a similar fate by taking poison, but the unfortunate German astronomer, Johan Wilhelm Wallot (1743-94), who had been employed on the testing of Leroy's chronometers and had lectured and observed in Paris for many years, perished on the scaffold on July 27 , the day before Robespierre fell and the prisons were thrown open. The 'father' of erystallography, René Just Haüy (1743-1822), born six months before Lavoisier, was at one time in danger, but friends came to his resoue. None took a more active part in the foundation of the metric system than Lavoisier, and in some of his measurements Haüy was associated with him. There is a statue of Condorcet near the French Institute, and statues of Lavoisier behind the Madeleine Church and at the Sorbonne. A reduced replica of the latter is in the National Gallery of Scotland.

The discoveries and theories of Lavoisier were embraced by some chemists and rejected by others, but the credit for their favourable reception in Germany was largely due to the tireless Martin Heinrich Klaproth, who was born on December I, 1743, and died on January 1, 1817. Klaproth made a host of accurate analyses of minerals and discovered several elements. In 1792, when professor of chemistry in Berlin, he proposed to the Berlin Academy of Sciences to repeat the more important of Lavoisier's experiments. His offer was accepted, and from that 